\title{
Unge kvinder og store følelser: Modernitet, melodrama og pubertet
}

Pubertet og store følelser hænger sammen. Det ved enhver, der har med unge mennesker at gøre, eller som blot har en nogenlunde levende erindring om sin egen ungdom. Pubertet og medier hænger også sammen. Unge er den befolkningsgruppe, der bruger flest forskellige medier, og medierne fungerer helt åbenlyst som sociale katalysatorer og psykiske prøverum. At gå i biffen, se video eller høre musik er ofte led i samværet med kammerater, og selve film- og musikoplevelsen giver mulighed for, at man kan eksperimentere med en voksen identitet og få hold på de følelsesudsving, der er så væsentlige og så vanskelige $\mathrm{i}$ puberteten.

Men unge kvinder og unge mænd foretrækker ofte forskellige medier og fortælleformer. Lige siden 1880 'erne, hvor de første læserunders $\emptyset$ gelser kom frem, kan man således konstatere, at piger læser mere end drenge, og at mønstret holder sig i voksenalderen. Også i dag er drenge og mænd mere visuelt orienteret, mens piger og kvinder $\mathrm{i}$ højere grad blander trykte og visuelle medier (Drotner 1991, kap. 1). Samtidig er det et gennemgående træk, at drenge og mænd foretrækker fakta, action og spænding, mens piger og kvinder ofte vælger fiktion og her især genrer, der sætter de personlige relationer i centrum. Disse kønsforskelle går på tværs af medietyper, og de er specielt markante i puberteten.

Jeg vil i det følgende analysere forholdet mellem kvindelig pubertet og unge kvinders foretrukne fortalleformer. Mere specifikt vil jeg argumentere for, at unge kvinders sociale og psykologiske dilemmaer i moderniteten gennemspilles med speciel tydelighed i det romantiske melodrama. Denne brede betegnelse omfatter en række narrative fællestræk, som vi kan finde både i bestsellere og ugeblade, i karlighedsfilm, samt i tv-seriernes soap 
operas og tele novelas. Der er selvsagt stor forskel på, om man analyserer en ugebladsnovelle fra 1880'erne, en kvindefilm fra 1920'erne - hvor de såkaldte maternal melos udvikles (Viviani 1987) - eller en nutidig tv-serie som Karlighed og magt. Alligevel er det slående, at der trods vigtige indbyrdes forskelle $\mathrm{i}$ handling, miljø og medieformer, også findes en række genkommende narrative mønstre og strukturer, som peger på to vigtige forhold: det romantiske melodrama er en uhyre popular fortælleform i moderniteten, og populariteten går på tværs af medietyper. ${ }^{1}$ Melodramaets vedvarende popularitet og dets æstetiske intertekstualitet mener jeg hænger snævert sammen med, at det romantiske melodrama til stadighed har haft sin vigtigste modtagergruppe blandt unge kvinder. Begge forhold må derfor undersøges ud fra denne gruppes særlige position i moderniteten.

\section{Kvindeforskning og melodrama}

Den moderne kvindeforsknings grundlæggende kritik af herskende forskningstraditioner har haft afgørende indflydelse også på medieforskningen. Den feministiske medieforskning har bidraget til to perspektivforskydninger: for det første retter man i stigende grad interessen mod mediemes reception i stedet for mediernes produktion. For det andet bliver man mere og mere interesseret $i$ at analysere medierne $i$ en kontekst $i$ stedet for medierne som en tekst. Disse perspektivforskydninger ser vi med forskellig vægt inden for den feministiske medieforsknings to hovedtraditioner: filmforskningen, samt forskningen i tv og trykt fiktion. Sidstnævnte skal omtales først.

I 1970'erne, hvor et af kvindeforskningens hovedmål var at afdække »glemte« kvindeerfaringer og -kulturer, begyndte en række medieforskere at undersøge, hvad den amerikanske filmkritiker Maria Laplace siden har kaldt »omløbet $\mathrm{i}$ den kvindelige diskurs« (the circuit of female discourse): bestseller-romaner, ugeblade, fanhæfter, kvindefilm, samt tv-serier rettet mod kvinder (Laplace 1987: 139). Det personlige og det følelsesmæssige danner grundpiller $\mathrm{i}$ dette omløb, og det er ikke tilfældigt, at det romantiske melodrama er en af dets narrative hovedhjørnesten. Denne kvindelige diskurs danner bunden i medieproducenternes hierarki, hvor nyhedsstof er toppen, men samtidig udgør det kvindelige omløb en vigtig forudsætning for, at disse producenter kan overleve. Denne modsætning mellem ideal og virkelighed er især tydelig inden for de kommercielle medier, hvor overlevelse er direkte afhængig af økonomisk omsætning. Men den findes også til dels i public-service medierne, som lever af politisk fastsat licensbetaling: formelt afhænger licensens størrelse af, om mediernes anses 
for at opfylde deres (folke)oplysende mission, men reelt afhænger den nok så meget af, hvorledes for eksempel Danmarks Radio og TV1 stiller sig i konkurrencen med de kommercielle medier om modtagernes gunst. Også i TV1 finder vi derfor elementer af den kvindelige fiktionsdiskurs.

De feministiske mediestudier vægtede ofte den empiriske grundforskning. De fulgte nøje kvindeforskningens konjunkturer, som de da også selv påvirkede: således analyserede man $\mathrm{i}$ begyndelsen mediernes kvindebilleder og lagde vægt på, hvorledes de undertrykker kvinder. Siden har man søgt også at afdække skjulte modstandsformer og sprækker i det ideologiske kit. Herhjemme kan vi spore denne udvikling ved at sammenligne bøger som Sфndags B.T. (Bolvig et al. 1971) og Udsigten fra det kvindelige univers (Møller et al. 1972) med Karen Klitgaard-Povlsens Blikfang (Povlsen 1986).

I udlandet, hvor den feministiske medieforskning i højere grad end herhjemme er præget af samfundsvidenskabelige metoder, foretages de empiriske undersøgelser ofte ved hjælp af kvalitative metoder som åbne interviews og deltagerobservation (Hobson 1982, Ang 1985, Radway 1984). Disse studier har været banebrydende for receptionsforskningen, men kvindeforskernes perspektiv er oftest bredere: man søger at analysere kvinders mediebrug som en del af deres samlede hverdagskultur. Nyere forskning vedrørende historisk mediereception indgår i denne sammenhæng (Modleski 1982, Drotner 1988).

I takt med, at kvindeforskningen op gennem 1980'erne er blevet stadig mere teoretisk selvbevidst, er den empirisk funderede medieforkning blevet suppleret - og kritiseret - af mere teoretisk orienterede studier. Disse finder vi især inden for den feministiske medieforsknings anden hovedtradition, nemlig filmforskningen, som især er udviklet i Nordamerika. Med udgangspunkt i den amerikanske filmteoretiker Laura Mulvey's klassiske artikel »Visual Pleasure og Narrative Cinema« (Mulvey 1975) har feministiske filmforskere analyseret, hvorledes Hollywood-filmen skaber narrative konventioner, der bygger på to grundforhold: filmen skjuler sig selv som tekst, og den prioriterer det mandlige blik. Disse to forhold tilsammen udelukker, at seeren kan være både subjekt og kvinde. Ligesom det er tilfældet inden for den mere empirisk orienterede medieforskning, er denne vægt på kvindeundertrykkelse senere søgt nuanceret, hvilket dog især har ført til, at feministiske filmteoretikere vender sig mod æstetiske former, der eksplicit bryder med Hollywoods fortællestil (de Lauretis 1987, Silverman 1988, Mulvey 1989).

Den feministiske filmtradition har Lacans psykoanalyse som sit teoretiske udgangspunkt. Denne tradition har bidraget afgørende til medieforskningen på tre områder: den har for det første vist, at den psykosemiotiske fil- 
manalyse, som den er udviklet af for eksempel franskmanden Christian Metz, er en kønnet analyse. Den har for det andet tydeliggjort, at både film og filmanalyse er kønnede konstruktioner. Den feministiske filmforskning har hermed udgjort en af pionererne i den postmoderne kritik af repræsentationens sandhedsværdi. Filmforskningen har for det tredje sat fokus på det romantiske melodrama som en speciel kvindelig fortalleform. Sammen med western- og krimi-genrerne har det romantiske melodrama domineret udviklingen af Hollywood som international drømmefabrik (andre populære kvindelige fortælleformer er musical og historiske dramaer). Kvindeforskerne har hermed bidraget til, at melodrama nu er ved at forlade sin Askepotplacering nederst i medieforskningens genre-hierarki, hvor krimien hidtil har været de mandlige middelklasseforskeres ukronede konge (fordi krimien er action uden blod?). Samtidig indebærer denne nyvurdering, at genrebegrebet udvides og analyseres $\mathrm{i}$ et kulturanalytisk perspektiv.

Feministisk filmforskning og den $\emptyset v r i g e$ feministiske medieforskning har hidtil levet hvert sit liv og har hver på sin måde bidraget til medieforskningens generelle vægtforskydning $i$ retning af reception og mediemes brugssammenhæng. Forskellene mellem de to traditioner viser sig i, at man inden for filmteori bevæger sig på tekstens niveau og beskæftiger sig med de forskellige positioner, som teksten tilbyder seeren (spectator). Omvendt inden for den øvrige medieforskning: her taler man om tilskuere (audiences), altså de mennesker af $k \varnothing d$ og blod, som ser film, tv eller reklamer (Kuhn 1984). De to traditioner rummer hver for sig flere og ofte modstridende retninger, og de lader sig ikke umiddelbart forene. Alligevel er det åbenlyst, at de gensidigt kan befrugte hinanden: filmteoretikere kan lære af de øvrige medieforskeres sensitivitet over for, at tekster aktualiseres, og at dette sker inden for forskellige kulturelle og historiske kontekster. Omvendt kan disse forskere lære af filmanalytikernes skepsis over for subjektets enhed: tekstlige aktualiseringer er symboler og kan ikke ligestilles med autentiske kvindetolkninger (tekstanalyse er altså ikke blotlæggelse af glemte kvindeerfaringer). Og reception er andet og mere end bevidst selektion af tilbudte koder i mediernes mangfoldige landskab.

Derudover er der to fællestræk ved traditionerne, som har særlig relevans for studiet af melodrama: for det første fokuserer de fleste kvindeforskere ligesom deres mandlige kolleger på et enkelt medium. Spørgsmålet om mediernes intertekstualitet falder herved uden for de analytiske rammer (se kritik in: Drotner 1990a). For det andet definerer kvindeforskerne direkte eller indirekte deres modtagere som voksne kvinder (hvad enten disse befinder sig på tekstens eller receptionens niveau). Spørgsmålet om forholdet mellem for eksempel alder og køn belyses ikke. Skønt det romantiske 
melodrama står så centralt i feministisk medieforskning, har man hidtil ikke tematiseret sammenhængen mellem melodrama og unge kvinder. Og det til trods for, at denne sammenhæng er så åbenlys i unges hverdagskultur.

\section{Popularkultur og unge kvinder}

Medier og modernitet hører sammen. De moderne erfaringer tematiseres og tolkes Iøbende af massemedierne, som selv næres af modemitetens grundlag: industrialisering, urbanisering, sekularisering og kommercialisering. Siden mediernes barndom har de kommercielle medieformer - ugeblade og familiemagasiner, film og reklamer - udgjort de fleste kvinders væsentligste indgang til den moderne kultur (Drotner 1988, kap. 8-10; Drotner 1990a). Populærkultur og specielt medierne bliver da også forbundet med det kvindelige: populærkulturen er både farlig og forjættende, den lokker med følelsesmæssig intensitet, men man(d) bliver samtidig tappet for sin rationelle dømmekraft. Denne diskursive sammenkobling af medier/kvindelighed/følelser/dæmoni er blevet fremhævet af flere populærkulturforskere (Huyssen 1986, Modleski 1986, Drotner 1990b). Men hvad med kvinderne selv?

De indskrives selvsagt $\mathrm{i}$ den herskende diskurs. Men samtidig bliver populærkulturen og ikke mindst de kommercielle medier de vigtigste offentlige tolkningsrum for kvinders følelser. Melodramaet er den narrative form, som måske mest direkte tematiserer netop følelsernes register. Det romantiske melodrama som fortalleform udvikles $i$ spandingsfeltet mellem mandlige diskurser om popularkultur som det kvindelige og så kvinders modernitetserfaringer, hvor følelser kobles til det personlige og det seksuelle. Dette spændingsfelt erfares særlig tydeligt af unge kvinder.

Moderne unge hører nemlig til populærkulturens pionerer. Efterhånden som barndommen forlænges og rammesættes af uddannelse, familie og kammerater snarere end af arbejde, opstår også en egentlig ungdomstid. Moderne unge har mere tid og flere penge til rådighed end tidligere tiders ikke-voksne, ligesom skolen giver dem en fælles erfaringsbasis, der selvsagt tolkes ganske forskelligt alt efter, om man bor i byen eller på landet, tilhører arbejderklassen, bondestanden eller middelklassen, er dreng eller pige. Penge, tid og fælles erfaringer er det råstof, som brugen af populærkultur skabes af. (Hertil kommer selvfølgelig en vis læsefærdighed for de trykte mediers vedkommende.) Det råstof har unge kvinder i moderniteten mere af end deres mødre og andre voksne medsøstre, omend de altid har haft mindre af det end unge mænd (Ungdomskommissionen 1951: 48-51; Alkjær 1956: 
15; Drotner 1991, kap. 2). Råstoffet holder den kvindelige kulturelle diskurs i omløb. Denne diskurs bliver på sin side et vigtigt forankringspunkt for unge kvinders identitetsdannelse og sociale netværk. Lad os tage filmens udvikling som eksempel på sammenhangen mellem diskurs og aktualisering.

I 1914 udgav den tyske sociolog Emilie Altenloh bogen Zur Soziologie des Kino. Undersøgelsen, som er baseret på studier af 2.400 spørgeskemaer i byen Mannheim, synes at være den første analyse af filmpublikummet opdelt på både alder (14 år og op), køn og social baggrund. Altenloh - som var elev af Max Weber - fandt, at $80 \%$ af alle adspurgte går i biografen. De ivrigste besøgende er unge, mænd i arbejderklassen, et stigende antal butiksog kontorfolk, samt kvinder i alle aldre (Altenloh 1914: 58-94). Altenlohs undersøgelse er vigtig af to grunde: Den viser, at kvinder og unge - og altså også unge kvinder - udgør en kernegruppe blandt biografpublikummet helt fra filmens barndom. Og den demonstrerer unge kvinders forkærlighed for melodrama:

»Allerede de 14-årige interesserer sig mest for kærlighedshistorier og ganske særligt de, der ligner pigernes eget liv, eller som kan afspejle glansen fra den store verden. Mest drejer (historierne, K.D.) sig om en kvinde af folket, hvis skæbne efter mange fejltagelser ender med hendes moralske undergang eller i 'stille lykke'. De fleste af den slags dramaer har et stærkt sentimentalt præg, hvilket fremgår af en række karakteristiske titler i (respondenternes, K.D.) svar: Moderens rose, Froken kvinde, En kvindes lidelsesvej, Kontorpigen, Kvindeskabner. Overalt står en kvindes føllelseskonflikter (Herzenkonflikte, K.D.) i centrum.« (Altenloh 1914: 89)

Althenlohs resultater bekraftes af senere undersøgelser fra andre Iande. I England udgør børn og unge under 17 år omkring 30\% af biografgængerne lige efter Første Verdenskrig (Briggs 1960: 18). I 1939 konkluderer sociologen Seebohm Rowntree i en omfattende undersøgelse af byen York, at »mere end halvdelen af biografernes publikum udgøres af børn og unge, og af de voksne er 75\% kvinder » (cit. in Richards 1984: 13). I USA udgør børn og unge ligeledes en betydelig andel af biografgængerne (Jowett 1976: $77 \mathrm{ff}$ ), og nyere studier af biografudlejernes arkiver har ligeledes vist, at middelklassen og unge kvinder af alle sociale lag tiltrækkes af film fra starten (Merrit 1976; Allen 1980). Som den amerikanske filmforsker Miriam Hansen fremhæver (Hansen 1983), må filmhistorikere herefter revidere deres gængse opfattelse af, at film er demokratiets løftestang for især mandlige arbejdere og indvandrere. Denne opfattelse grundlægges allerede $\mathrm{i}$ filmens 
barndom, hvor det nye medium beskrives som »arbejderens universitet«, »demokratiets teater« - ja selv »øjets esperanto«, fordi stumfilmen trodser sproglige og sociale barrierer, og derfor menes at fungere som en kulturel og moralsk melting pot i fuld overensstemmelse med de amerikanske idealer (Jacobs 1968, Jowett 1976).

Filmen må snarere betragtes som et tolkningsrum, både fysisk og symbolsk, hvor kulturelle modsætninger mødes og søges medieret. Ud fra en række interviews med immigranter, beskriver medieforskerne Elizabeth og Stuart Ewen i bogen Channels of Desire (Ewen og Ewen 1982), hvorledes det nye filmmedium bliver mange immigrantkvinders vigtigste kulturelle katalysator, ikke blot til the American way of life, men til the American way of life: der er ikke blot tale om akkulturation gennem assimilation til det amerikanske, men om akkulturation gennem konsum. Dette konsum er især kvindernes domæne. At gå i biografen er en del af dette konsum, og i selve filmene kobles nye forbrugsmønstre til nye definitioner af, hvad kvindelighed er. Ifølge Ewen og Ewen er det især Cecil B. de Mille, som i 1920'erne tematiserer et populærkulturelt hovedtema i moderniteten, nemlig »metamorfose gennem konsum « (Ewen og Ewen 1982: 100).

USAs immigranter (23 millioner fra Syd- og Østeuropa i perioden 18901920) nævner jeg her, fordi deres kulturelle situation for mig at se tydeliggør nogle af de vigtigste transformationer, som generelt kendetegner moderniteten (individualisering, brud, kulturel kommercialisering, feminisering af forbrug). Også i andre lande som for eksempel Danmark, hvor modemiteten er et senere fænomen og i højere grad præges af migration (land-by) end af emigration (hjemland-udland), indebærer den sociale og økonomiske modernisering en dynamisering og labilisering af vante kulturelle mønstre og normer. Ifølge Ewen og Ewen slår disse ændringer stærkest igennem i familien, hvor kvinderne har hovedansvaret for børneopdragelsen: "Det nye byliv underminerede den traditionelle kvindeligheds grundlag og tvang kvinder til at vende sig $i$ to retninger pa en gang: til fortiden for at hente styrke til nutidens liv og til fremtiden for at finde nye overlevelsesmuligheder« (Ewen og Ewen 1982: 81).

Disse modsatrettede krav skaber især modsætninger i forholdet mellem mødre og døtre, som traditionelt er de, der sikrer hverdagens kulturelle kontinuitet. Bedre uddannelse, fabriksarbejde og senere kontor- eller butiksarbejde, giver unge kvinder en ny autonomi. Denne autonomi udtrykker de for eksempel »i byernes ungdomskultur, [der fungerer] som et værn mod patriarkalske former for seksuel kontrol« (Ewen og Ewen 1982: 95). Modernitetens dynamisering tenderer mod at svække båndene mellem 
generationerne, men til gengæld styrkes båndene inden for generationerne. Unge får både et større behov og bedre muligheder for at skabe deres egne symbolske rum. Det sker i vidt omfang i de moderne ungdomskulturer, i hvilke filmen bliver et vigtigt element. Det anerkendes da også af mange mødre, hvad enten de modsxtter sig eller misunder døtrenes selvstændighed. Således siger Maria Zambiello, en italiensk immigrant, som kom til USA i 1903 og fik tre børn:

"Jeg føler mig ikke så god som de amerikanske kvinder, fordi jeg er gammeldags, fra den anden side ... De har også andre vaner. Vi lægger hænderne på bordet, det gør de ikke. Det er derfor, jeg ikke føler mig så god. Men de unge italienske piger, mine døtre, de er up to date, ligeså gode, ligeså høflige som amerikanerne. De er født her, de går i skole sammen, de ser de samme film, de ved det.« (Ewen og Ewen 1982: 103)

Unge kvinder udgør en så stor del af publikum, vil jeg hævde, fordi biografen tillader, at private temaer, som i moderniteten bliver centrale dilemmaer i unge kvinders hverdagsliv (seksualitet, mellemmenneskelige relationer, personligt udseende) tematiseres i en offentlig sammenhæng. Og denne tematisering sker vel at mærke både på lærredet og i salen. Melodrama er både en del af fiktionen og en del af livet.

Det er det også herhjemme. Faktisk er den første egentlige danske spillefilm et melodrama, nemlig Den hvide slavehandel fra 1910, som fik kæmpesucces og blev efterlignet af udenlandske selskaber. Som i USA tiltrækker filmen fra starten forskellige sociale lag. Den første filmforevisning sker i 1896 i Pachts forlystelsesetablissement i København, og film fortsætter med at udgøre en del af underholdningen i hovedstadens pæne varieteer, indtil man etablerer egentlige biografer - disse betegnes da også meget nydeligt som morskabs- eller biografteatre. I provinsen introduceres bredere kredse til det nye medium ofte via markedspladsernes rejsebiografer eller i de såkaldte butiksbiografer (Dinnesen og Kau 1983: 27). Som i udlandet udgør børn og unge meget væsentlige dele af publikum. Det antydes allerede $\mathrm{i}$ den udvalgsbetænkning, som danner grundlag for den første egentlige filmlov i 1922 (citatet genfindes næsten ordret $i$ udvalgsbetænkningen til filmloven af 1933):

»Udvalget har været enigt om, at der ved en lovgivning om biografvæsenet må arbejdes med det hovedformål for øje at nå frem til, at der kun forevises film, der kan virke forædlende og belærende på 
publikum, særlig på den ungdom, som udgør det store flertal af dem, der søger biografteatrene.« (cit. in Dinnesen og Kau 1983: 33)

I 1930'erne, hvor filmen er den dominerende forlystelse, kommer de flittigste biografgængere »fra de mellemste og lavere sociale lag (kontorpersonle, arbejdere, husmødre, husassistenter o.l.), og aldersmæssigt [er] de fleste mellem 15 og 35 år « (Dinnesen og Kau 1983: 85). Unges filmvaner unders $\varnothing$ ges første gang i 1946 som led i Ungdomskommissionens omfattende kortlægning af de 15-25 åriges uddannelse, arbejde og fritid. Det fremgår, at mænd går hyppigere i biografen end kvinder, og at biografbesøgene topper i 16-20 års alderen. ${ }^{2}$ Blandt de ugifte unge mænd findes de flittigste biografgængere i provinsbyerne, mens det for kvindernes vedkommende er i København - de unge, der bor på landet, ser færrest film. Urbanisering og film hænger altså sammen. I gennemsnit går omkring $60 \%$ af unge mænd i byerne i biografen mindst en gang om ugen, mod ca. $40 \%$ af de unge kvinder. De fleste foretrækker udenlandske - specielt amerikanske - film, og danske film er især populære i landområderne (Ungdomskommissionen 1951: 138, 139). Amerikanske film udgør på det tidspunkt omkring halvdelen af det samlede udbud og danske film kun 3\% (Dinnesen og Kau 1983: 230). Igen en understregning af, at Hollywoods opskrift på kulturel modernisering bliver tattest knyttet til det moderne byliv også herhjemme (Ungdomskommissionen 1951: 138, 139). De unges filmvalg ledsages af følgende kommentar:

»de unge ser væsentligt bedre film i byerne, navnlig i hovedstaden, end i stationsbyerne og i landkommunerne. Det er imidlertid klart, at dette også hænger sammen med de lokale biografers repertoire og mulighederne for at forstå en fremmedsproget film og ikke siger noget om ungdommens mere eller mindre gode oprindelige smag. Det kan videre ses, at film med et sentimentalt eller psykologiserende grundpræg i højere grad ses af unge piger end unge mænd, mens spændingsfilm fortrakkes af det »stærke $k \emptyset n, o g$ at de egentlige farcer i det omfang, hvori disse forekommer, også har deres største publikum blandt de unge mænd - navnlig i de yngste aldersklasser.« (Ungdomskommissionen 1951: 142-43)

Ser vi bredt på forholdet mellem film og unges kultur, finder vi altså, at der meget tidligt etableres et mønster hos biografpublikummet, som genfindes på tværs af historiske og nationale skel. Også i dag er unge de, der går mest i biografen, selvom billetsalget er faldet fra 1950'ernes rekord på 56 
millioner om året til 11 millioner i 1987, og skønt faldet er mest markant blandt unge (Berthelsen 1989: 128; Fridberg 1989: 43). Det er også stadig sådan, at unge mænd er lidt mere ivrige biografgængere end unge kvinder (og langt gladere for at se video). $\mathrm{Og}$ det er ligeledes sådan, at de to $\mathrm{k} \emptyset \mathrm{n}$ foretrækker forskellige genrer. Skønt man finder melodramatiske træk også i mandlige fortælleformer, er det romantiske melodrama fortsat primært en sag for kvinder.

\section{Feminisering af filmdiskursen}

At unge og kvinder fra starten hører til biografernes kernepublikum, og at de ofte foretrækker det romantiske melodrama, præger $\mathrm{i}$ h $\emptyset \mathrm{j}$ grad diskursen om film som massemedium: det bliver enten infantiliseret som ikke-seriøs underholdning, eller det bliver, hvad der er mere vanligt, feminiseret som farlig forførelse. Nedvurderingen af kvindelige fortælleformer finder vi i citatet ovenfor fra Ungdomskommissionen (»film med et sentimentalt eller psykologiserende grundpræg«), som også her viser, at denne nedvurdering sker inden for kommissionens normative kulturopfattelse (»ungdommens mere eller mindre gode oprindelige smag«). Allerede hos Emilie Altenloh finder vi en kritisk kobling mellem film og kvinder:

»Kvindekønnet, som siges at opfatte indtryk og følelser $\mathrm{i}$ deres helhed, må være særlig påvirkelig af filmisk repræsentation. I sammenligning med dem synes det næsten umuligt for intellektuelle mennesker at genkalde sig i detaljer disse adskilte handlingssekvenser.« (Altenloh 1914: 91)

Altenloh ligestiller film, følelser og kvinder, og hun gør det gennem modsætninger: intellektuelle menneskers (mænds?) rationelle dømmekraft. At film og følelser hænger sammen er en grundlæggende erfaring: billeder bevæger, idet de bevæger sig. Men det synes altså ligeså grundlæggende, at denne skuelyst forbindes med det kvindelige. ${ }^{3}$ Denne kobling findes hos de fleste modstandere af filmmediet fra præster til borgerlige politikere: det kyindelige forbindes med forførelse, hvilket antyder filmmodstandernes angst for henførelse, for det ukendte »andet « - i det hele taget angsten for at opgive den rationelle bevidsthed, som er den mandlige borgers kendemærke.

Men den nedvurderende kobling findes ligeledes hos filmens tilhængerne. Den tyske journalist og kulturkritiker Siegfried Kracauer, som oprindelig var ingeniør, tilhører gruppen omkring den tidlige Frankfurterskole, som blandt 
andet tæller Ernst Bloch, Walter Benjamin, samt Horkheimer og Adorno. Ligesom for eksempel Benjamin betragter Kracauer filmen som et progressivt medium, idet den er frigjort fra kunstens produktionsvilkår og æstetiske konventioner. Men som journalist ved den liberale Frankfurter Zeitung i perioden 1921-33 er han samtidig vidne til, at publikum sjældent foretrækker den dokumentarisme og realisme, som udgør hans egne æstetiske idealer. Kracauers har beskrevet sin reaktion på dette dilemma i sin kendte artikel "Die Ornament der Masse" fra 1927: industrialisering og rationalisering medfører en kulturel og bevidsthedsmæssig ensretning, der umuliggør individuel refleksion og kritik (Kracauer 1927).

Samme år udgiver han - ligeledes i Frankfurter Zeitung - artikelserien "Film und Gesellschaft«, som siden har fået den mere betegnende titel »Die kleinen Ladenmädchen gehen ins Kino«. Kracauer beskriver her de filmtyper, som især bliver set af »den lille ekspeditrice« og »kontormusen « (die Tippmamsell). Artikelserien er et vigtigt dokument af to grunde: den viser, at unge kvinder udgør en så vigtig del af biografpublikummet, at de er synlige for Kracauers kritiske blik. Og den er et af de tydeligste eksempler på, hvorledes også den radikale kulturdiskurs først feminiserer filmens lystoplevelser for herefter at afskrive deres værdi.

Kracauers synsvinkel er den ideologikritiske: »de vanvittige og virkelighedsfjerne filmfantasier er samfundets dagdrømme, i hvilke den egentlige virkelighed kommer til udtryk, som ellers formes som undertrykte ønsker (Kracauer 1977: 280). Det er kritikerens opgave at afsløre disse dagdrømme som fiktive, at blotlægge »den egentlige virkelighed« og herved skærpe modtagernes kritiske sans: indsigt avler modstand. Som led i denne åndelige arkæologi analyserer Kracauer en række eksempler på populære filmgenrerog temaer: krigsfilmen, det historiske drama, den eksotiske film, forviklingshistorien, samt kærlighedsfilm og melodramaer. ${ }^{4}$ Indholdsanalyserne afsluttes med en kort bedømmelse af filmenes reception.

Stilen er ironisk distancerende. Saledes hedder det om den historiske film: "Heltemodet $\mathrm{i}$ filmene er omvendt proportionalt med tilnærmelsen til samtiden«. I den eksotiske film hjælper rejselivet »fantasien på gale veje, det skjuler udsigten med indtryk, det åbenbarer verdens herligheder, så dens hæslighed glemmes ... Når samtlige geografiske afkroge er blevet fotograferet, er samfundet blevet totalt blindt. De små ekspeditricer ville så gerne forlove sig ved Rivieraen« (Kracauer 1977: 281, 288).

Kracauers analytiske kølighed forvandles imidlertid til nedladende kynisme, når han omtaler kærlighedsfilm og melodramaer. Han beskriver for eksempel heltinden $i$ en film, hvor en ung kvinde forklæder sig som kammertjener for at vinde sin udkårne, som »et tvetydigt væsen $i$ entydige 
situationer«. Den unge mand er naturligvis ikke alene smuk, men også rig, og således er heltindens kærlighed fra starten smittet af materialismens nødvendighed:

"Erhvervet hedder erotik, beskæftigelsen med det hedder livet. Livet er de bemidledes opfindelse, som de ubemidlede efteraber efter ringeste evne. Eftersom interessen $i$ at bevare samfundet ligger hos de besiddende kredse, må de forbyde folk at tænke over det. Ved pengenes hjælp lykkes det dem i fritiden at glemme den eksistens, som de dagligt slider for. De lever. De køber sig amusement, som tillader tankeorganet at fordufte, men som taler tydeligt til de øvrige organer ... Det lys, som [kærligheden] udsender, er så festligt, at menneskene overhovedet ikke $\emptyset$ nsker, at der skal gå noget andet lys op for samfundet. Især når kærligheden er sikret finansielt. I det dunkle tilskuerrum griber de stakkels små ekspeditricer deres ledsagers hånd og tænker på den kommende søndag.« (Kracauer 1977: 285)

Kracauer beklager, at kærligheden således besmittes og antyder hermed, at han har en tro på den rene kærlighed. Denne tro bliver så meget desto mere påfaldende, eftersom han i samme åndedrag afskriver de kvindelige tilskuere som barnlige sjæle, der henføres af kærlighedens illusion, fordi de åbenbart savner rationel dømmekraft. Kærligheden som utopi kan kun bevares ved at eksternalisere og nedvurdere dens udtryk (det kvindelige, det materielle). I omtalen af en anden kærlighedsfilm taler Kracauer ligefrem om, at den får ekspeditricerne til »at længes efter den dag, da de kan antænde en ung berliner med deres dumme hjerter (Kracauer 1977: 289).

Det er dog melodramaet, som Kracauer har størst foragt for. Han analyserer en film om forpasset kærlighed (et af melodramaets narrative grundformer: manden frier, men kvinden kan/vil ikke sige ja. Når kvinden så siger ja, er det for sent. Eller: kvinden vil sige ja, men manden kan/vil ikke, osv). I den pågældende film tager kvinden gift til slut for at redde sin elskedes officerskarriere, og Kracauer bemærker hertil:

»Døden, som understøtter de herskende institutioners magt, forhindrer den $d ø d$, der tjener til at bekæmpe magten ... Der findes mange mennesker, som heltemodigt ofrer sig, fordi de er for dovne til at gøre oprør; der udgydes mange tårer, som kun flyder, fordi det ofte er lettere at græde end at tænke sig om ... Publikum er så rø̆rt over de giftudladninger, som de flyder hen i, at de end ikke ønsker at uddrive giften. Kun anstrengelsen med at afgifte samfundet kan således kaldes 
tragisk. De små ekspeditricer tører i hemmelighed øjnene og pudrer sig hastigt, inden lyset tændes." (Kracauer 1977: 292-93)

Når kærlighedsfilmene ender lykkeligt, er det pengenes skyld. Og det er slemt. Men når kærligheden ender ulykkeligt, er det dødens skyld. Og det er værre. Her kommer selv Kracauers kritiske rationalitet og sociale utopier til kort. I begge typer film er det dog det unge kvindelige publikum, der barer bevisbyrden, mens Kracauer er dommeren. De juridiske associationer sørger han selv for i sin foromtale af artikelserien: her beder han læseren betragte den som »et lille mønsterhæfte, hvis skoleeksempler underkastes moralens kasuistik « (Kracauer 1977: 282). Krakauer sætter lighedstegn mellem æstetisk udtryk og bevidsthedsmæssige indtryk. Hans eksplicitte $\emptyset$ nske om at bevidstgøre læserne (og de unge kvinder?) negeres dog bestandigt af hans ironisk distancerede skrivestil. Den gør, at vi som læsere hæver os lige så højt over publikum som Krakauer selv, og både forfatteren og vi undviger hermed at tage seriøst stilling til de behov og motiver, som fascinerer de unge kvinder - endsige anerkende dem hos os selv. ${ }^{5}$ Kracauer uskyldiggør ikke film som barnlig underholdning. Han dæmoniserer heller ikke direkte film som kvindelig i lighed med mange konservative kulturkritikere. Hans (ubevidste) strategi er mere indirekte. Hans distancerede blik spidder den kvindelige fascination for dernæst at skjule denne fascination som en forførende illusion.

Jeg har beskrevet Kracauers analyse temmelig detaljeret af to grunde: han repræsenterer så tydeligt den intellektuelt reflekterede mands dilemmaer med de store følelser på film. Og disse dilemmaer kaster et nyt lys over den kritiske kulturanalytiske sensitivitet, som Kracauer både herhjemme og i udlandet er så berømt for. Troen på oplysningens rationalitet er en mandlig utopi. Den forudsætter ikke alene en diskurs, der splitter følelse og fornuft, offentlig og privat, men kræver tillige, at denne opsplitning fastlåses i kønnets dikotomi. Når postmodernister og feminister i dag sætter spørgsmålstegn ved oplysningstroen, er det derfor ikke underligt, at kønnet står i fokus i forsøget på at redefinere både fornuft og følelse som begreber og som relationer. For at forstå unge kvinders vedvarende fascination af det romantiske melodrama lad os da se nærmere på, hvad der karakteriserer det som æstetisk udtryk. 


\section{Melodrama som narrativ form}

Hvad strukturerer melodrama som narrativ form? Det gør polarisering. Melodramatiske fortællinger bygger på kontraster. Disse kontraster er struktureret som moralske modsætninger, og handlingen udspiller sig som en manikæisk kamp mellem det gode og det onde. Den amerikanske litteraturkritiker Peter Brooks karakteriserer i bogen The Melodramatic Imagination fra 1976 melodramaet som modernitetens svar på tragedien: den indsigt $\mathrm{i}$ egne normbrud, som er betingelsen for tragediens katharsis-effekt, er ikke mulig i moderniteten, der bestandig underminerer entydige sociale normer, man kan måle sig selv i forhold til - både i fiktionen og i livet. Etikken bliver dynamiseret og den bliver personliggjort. Brooks definerer herudfra melodramaet som »et semantisk kraftfelt« (a semantic field of force). Det artikulerer moralske ekstremer som personlige dilemmaer, hvis løsning »ikke så meget afhænger af dydens sejr som af, at den gør verden moralsk forståelig (Brooks 1976: 42).

Også selve det narrative forløb karakteriseres af polarisering. Fortællingens kronologi brydes regelmæssigt af sekvenser, som rykker os ud af tid og sted: stormen begynder at piske mod ruden, idet heltinden modtager et afskedsbrev fra sin elskede, eller heltens sande identitet afsløres, netop som han skal hænges for et mord, han ikke har begået. I litteraturen er det ofte farve- eller naturbeskrivelser, der markerer disse brud, i visuelle medier er det ofte musik, lyssætning eller mise en scène. Disse sekvenser bringer ikke handlingen videre, men skaber tilstande, der tillader, at tilskueren eller læseren for en tid tilsidesætter sin lyst til at vide, hvad der videre sker, for i stedet at flyde hen $\mathrm{i}$ emotionelle intensiteter.

Handling og stilstand, kognition og emotion, spænding og patos veksler i melodramaet. Denne vekslen spiller samtidig på modsætningen mellem det kendte og det ukendte: den realistiske fortælling, hvor tid, sted og personer er genkendelige, brydes af tilstande, hvor den narrative progression perspektiveres eller ligefrem modsiges. (Historisk trækker melodramaet på to litterære traditioner, nemlig den realistiske tradition (the novel of sentiment, le roman social) og den gotiske tradition i drama og litteratur.)

Melodramaets strukturelle og tematiske brud analyseres ofte i psykoanalytiske termer som former, der tillader det undertryktes tilbagekomst. Det er også Brooks' tolkning, og han taler i den forbindelse om, at melodramaet rummer en "stumhedens tekst«, der udtrykker betydninger, som undviger sproget og det Symbolske i Lacans forstand. Det er ikke mindst denne psykologiske funktion, der $\mathrm{g} ø \mathbf{r}$, at melodramaet vedbliver at være populært. Hertil kommer formens fleksibilitet, som Brooks fremhæver det: melodra- 
maet insisterer ikke på bestemte normer, men fastholder, at normativitet som sådan findes. Det er denne fleksibilitet, vil jeg mene, der mere end noget viser, at melodramaet er en moderne fortælleform.

I modsætning til Brooks vil jeg også understrege, at melodramaet ikke blot tjener til at skabe moralsk afklaring. Det er tillige en fiktionsform, som tilbyder lystoplevelser. Man læser romaner, ser film og tv, fordi man vil, ikke fordi man skal. Denne lyst hænger snævert sammen med dynamikken i den narrative proces: den rummer subjektpositioner, der tillader, at man kan pendle mellem det genkendelige og det fremmede, mellem indlevelse og distance, mellem progression og stasis, mellem spænding og patos. Denne dynamik findes i de fleste fiktionsformer, men i melodramaet er det fiktionens omdrejningsakse. I det romantiske melodrama er denne dynamik af en særlig karakter.

Det romantiske melodrama er kendetegnet ved, at de moralske modsætninger udtrykkes og tolkes som følelsesmaessige dilemmaer. Hovedpersonen ęr en kvinde. Det romantiske melodramas narrative motor er således en symbolsk produktion og bearbejdning af kvindelig lyst. (Typiske mandegenrer som westerns og krimier kan ligeledes indeholde melodramatiske træk. Men her udfoldes de moralske dilemmaer i handling, og som regel i offentlige rum - western-helten græder kun over at miste sin hest, ikke sin kæreste.) Det romantiske melodrama udvikles i det 19. århundredes drama og litteratur og får sin filmiske parallel i mellemkrigstidens kvindefilm (som igen ofte bygger på romaner). Disse film udgør en af hovedpillerne i Hollywoods internationale gennembrud, og det er specielt dem, Kracauer og andre intellektuelle mænd ironiserer over.

Set i lyset af, at det romantiske melodrama tematiserer dilemmaerne $\mathrm{i}$ kvindelig lyst, bliver det tydeligt, at hvad der eksplicit er en politisk og astetisk kritik, tillige rummer en implicit angst for hengivelse og en aggression over for kvinders lystudfoldelse. Hertil kommer selvfølgelig den trussel mod mands etablerede økonomiske og politiske magt, som nye kvindeerhverv repræsenterer. Både ekspeditricer og kontordamer rokker den borgerlige offentligheds idealer på to fronter: de overskrider kvindens placering $\mathrm{i}$ intimsfæren, og de personificerer konsumsamfundet. Disse nye erhverv står ikke alene i modsætning til husmoderens arbejde i hjemmet, men også i modsætning til kvinders arbejde i landbruget eller på fabrik. 


\section{Melodrama og pubertet}

Det centrale tema i det romantiske melodrama - dets symbolske produktion og tolkning af kvindelig lyst - polariseres ofte narrativt i en modsætning mellem autonomi og afhoengighed. Denne modsatning er måske mere end noget den arv, moderniteten giver til kvinder, som vi har set det i beskrivelserne af filmens opkomst. Denne modsætning ytrer sig naturligvis forskelligt, alt efter om man lever i USAs indvandrerkvarterer omkring århundredskiftet, i Sydtysklands agrare samfund i 1920 'erne, eller i dagens Danmark. Men set i forhold til det samlede livsl $\varnothing b$, finder modsætningen mellem autonomi og afhængighed måske sit tydeligste udtryk hos unge kvinder, fordi de på en og samme tid konfronteres både med de psykologiske og sociale aspekter i modsætningen.

På det psykologiske niveau er modsætningen mellem autonomi og afhængighed grundlæggende en konflikt, der vedrører lighed og forskel i forhold til moderen: pubertetspigen genopfører og bearbejder sin barndoms balanceakt om både at blive ligesom mor (kønsidentifikation) og være forskellig fra mor (individ-identifikation). I det heteroseksuelle udviklingsforløb identificerer den lille pige sig med sin mor. Men for at kunne gøre det, må hun samtidig anerkende sin mors magt både reelt og i fantasien. Gennem denne identifikation opnår pigen en indre stabilitet som køn (»kvinde«), men omkostningen er, at hun forbliver afhængig af moderens magt og kærlighed. Den lille pige står $\mathrm{i}$ et dilemma, som skaber usikkerhed (elsker mor mig tilstrækkeligt?) og vrede (nej hun gør ikke). For at bevare sin integritet som individ vender hun sin kærlighed mod faderen, som er den nærmeste repræsentant for forskel. Penis bliver pigens lystmediator, hendes markering af forskel. Som den franske psykoanalytiker Janine Chasseguet-Smirgel siger det: »Penismisundelse er $\mathbf{i}$ grunden ikke andet end det symbolske udtryk for et andet $\emptyset$ nske. Kvinden vil ikke være en mand, men frigøre sig fra sin mor ved at blive fuldstændig, autonom, kvinde« (Chasseguet-Smirgel 1980: 87).

Ifølge denne revision af Freuds klassiske teori om Ødipus-komplekset indebærer kvinders heteroseksuelle udvikling en stadig spænding mellem autonomi og afhængighed, mellem integritet som invidid og identifikation som kvinde. I puberteten bliver denne spænding reaktiveret og gennemspillet i mor-datter konflikter, der ofte er voldsomme kriser for begge parter, fordi moderen selvsagt også er datter, og fordi konflikterne berører meget tidlige driftsmodelleringer og -undertrykkelser. ${ }^{6}$

Spændingerne på det psykologiske niveau mellem afhængighed og autonomi har deres parallel på det sociale niveau: her må unge kvinder balancere mellem kærlighed og karriere. Ganske vist har kvinder altid 
arbejdet, men det er først i moderniteten, at forholdet mellem ægteskab og erhverv bliver et modsætningsforhold. Indtil efterkrigstiden udtrykkes denne modsatning for de flestes vedkommende $\mathrm{i}$ en bestemt livsfase, nemlig $\mathrm{i}$ ungdommen: karriere og ægteskab udelukker hinanden, og det er i ungdomsårene, at kvinder vælger side. (For eksempel bliver lærere ofte afskediget, når/hvis de gifter sig.) For mange kvinder ikke mindst fra arbejderklassen har det ikke været vanskeligt at fravælge et lavt betalt job som tjenestepige eller rengøringshjælp. Men i mellemkrigstiden udvikler de servicefag sig for alvor, som forlener lav $1 \varnothing \mathrm{n}$ og lang arbejdstid med det moderne bylivs skær af luksus og fornøjelser. Ligesom de unge indvandrerkvinder i de første årtier af århundredet, tilhører Kracauers ekspeditricer netop den gruppe af unge kvinder, for hvem stormagasinerne er et behageligt alternativ til skrigende unger og kolde køkkener - også selvom de står på den forkerte side af disken.

I dag er modsætningen mellem karriere og kærlighed imidlertid ikke del af en livsfase, den er et livsperspektiv: så godt som alle unge kvinder regner med at have erhvervsarbejde, også selvom de er gift og/eller har børn (Drotner 1991, kap. 2). Det skærper konflikterne, hvilket da også viser sig i de modsætningfyldte budskaber, som både mødre, lærere og socialarbejdere giver unge kvinder i dag: skaf dig en uddannelse og et arbejde, men glem ikke, at du også er pige (læs: dyrk dig selv og dit ansvar for at opfylde andres behov). Balancegangen er blevet sværere, og den vanskeliggøres yderligere af, at karriere og ægteskab stadig defineres og erfares som modsætninger, der udelukker og ikke supplerer hinanden.

I puberteten er modsætningen mellem autonomi og afhængighed særlig intens, fordi den udfolder sig samtidigt på det psykologiske og det sociale plan. Unge kvinder skal ligesom deres mandlige kammerater være målrettede og satse på at klare sig i kampen om at blive det, de gerne vil, eller ville det, de kan. Samtidig oplever de en emotionel turbulens, når de skal bearbejde intense følelsesmæssige og seksuelle spændinger, en turbulens som ikke bliver mindre af, at p-pillen har øget det seksuelle præstationspres. Hverdagen stiller de unge kvinder over for modsatrettede krav, som søges løst $\mathrm{i}$ hverdagskulturen og dennes forskellige symboliseringer. I disse symboliseringer spiller medierne som nævnt en uhyre vigtig rolle.

I moderniteten udg $ø$ r unge kvinder til stadighed et vigtigt, men ofte overset, mediepublikum. De medvirker afgørende til at holde den populærkulturelle kvindediskurs i omløb, en diskurs hvor melodramaet har en høj stjerne. Set i lyset af denne kulturelle position, kan vi fastslå, at melodramaets vedvarende popularitet som moderne fiktionsform hænger snævert sammen med de sociale og psykologiske modsætninger, som tilspidses i den 
kvindelige pubertet, skønt de selvfølgelig udgør en generel resonansbund i det moderne kvindeliv. (Det er jo heller ikke kun unge kvinder, der læser romanblade og ser soap operas.) Melodramaets moralske polariseringer, dets følelsesmæssige intensiteter, samt bearbejdelsen af kvindelig lyst er så inciterende, fordi disse temaer allerede er omdrejningspunkter $i$ unge kvinders hverdagsliv.

Som næunt bearbejder det romantiske melodrama moralske konflikter som personlige dilemmaer. Herved forbindes modtagernes sociale erfaringsregister (det moralske, det offentlige, det kollektive) med deres psykologiske erfaringsregister (det emotionelle, det private, det individuelle). Broen er bearbejdelsen af kvindelig lyst. Denne lyst konstitueres netop gennem modsætningen mellem de to registre, der altså på en gang bliver lystens årsag og løsningsmodus. Polariseringen gør, at kvindelig lyst bliver defineret som et problem, men forsøgene på at løse dette »problem« rummer tillige sine egne lystoplevelser. Den astetiske polarisering af fortallingens fortløbende drive og så dens ophobede følelsesintensiteter giver de unge kvinder en usædvanlig mulighed for en imaginar pendling: fortællingens patos åbner for, at de kan udleve emotioner og eksperimentere med seksuelle fantasier, samtidig med at fortællingens spænding så at sige lukker for henførelsen igen: de unge kvinder undviger herved de pres, mange af dem finder $\mathrm{i}$ virkelighedens seksuelle møder. Disse polariseringer veksler ofte med hinanden, men de kan også findes samtidig - denne samtidighed er blandt andet grunden til, at vi græder uden at »ville« det!

Det romantiske melodramas popularitet må videre forstås i sammenhæng med, at dets æstetiske polarisering tillader et vekselspil mellem psykisk progression og regression, hvilket er en afgørende proces for begge $k \emptyset n$ i en del af puberteten: man har lyst til at vende tilbage til det lille barns sammensmeltning med omverdenen, og man er samtidig bange for atter at blive afhængig af far og især mor. Man genoplever smerten over den tabte enhed og angsten for at vare alene $\mathrm{i}$ verden. Men man møder også aggressionerne, som knytter sig til at frigøre sig og skabe sin egen identitet. Psykologisk set er denne vekselvirkning vigtig som katalysator for, at man kan rette sine driftsenergier mod nye (drifts)mål. Amerikaneren Peter Blos, som er en af de psykologer, der mest indgående har beskæftiget sig med (mandlig) pubertet, benævner dette som »en regression i jeg'ets tjeneste« og citerer i den forbindelse Nietzsche: »De siger, han går baglæns, det gør han også, for han vil prøve at tage et stort spring (Blos 1969: 114).

Det romantiske melodrama, hvis æstetik netop konstitueres gennem polarisering, passer som hånd i handske til denne psykologiske proces. De følelsesmæssige intensiteter rummer mulighed for, at modtagerne kan opleve 
en situation, der ligner (men ikke er lig med) det lille barns symbiotiske enhedsoplevelse. Heri ligger lysten ved hengivelsen. Men denne hengivelse fører tillige angst og smerte med sig. Handlingens progression begrænser imidlertid hengivelsen og $\mathrm{g} \emptyset \mathrm{r}$ herved angsten udholdelig. Livet går videre både for fortællingens heltinde og for dens modtagere.

Endelig må det romantiske melodramas popularitet ses i sammenhæng med det metamorfose-tema, der som nævnt bliver populært i Hollywoods kvindefilm i 1920'erne, og som vi senere genfinder i en del melodramaer. At man kan forvandle sig selv både på det ydre og det indre plan har selvsagt en generel appel i moderniteten, som bygger på labilisering. Forvandlingstemaet får dog speciel betydning i ungdomsårene, hvor psykologiske, sociale og kulturelle forandringer spiller sammen og spiller mod hinanden: man både kan og skal forandre sig. Disse forandringer bliver derfor kilde til dyb frustration såvel som åbenlys tilfredsstillelse. Metamorfose-temaet tillader unge af begge $k \emptyset n$ en fiktiv gennenspilning af disse modsætninger, og denne gennemspilning udtrykkes vel at mærke symbolsk som en transformation af kroppen: man bliver en anden ved at se anderledes ud.

I det romantiske melodrama knyttes kroppens ydre transformationer eksplicit til kvindelighedens indre. Disse ydre tegn bliver både årsag til og bevis for bevidsthedsmæssige og seksuelle forvandlinger, som ikke så let kan symboliseres. (Vi ved alle sammen, hvad klokken har slået, når heltinden lægger brillerne.) Præcis kroppens ændringer er jo i puberteten de tydeligste tegn på voksenlivet, samtidig med at disse ændringer er de sværeste at kontrollere. Det giver den imaginære modellering så stor symbolsk værdi. At voksne forskere med analytisk indsigt samtidig kan påpege, at heltinden herved for alvor underkaster sig det mandlige blik (manglende syn, manglende indsigt), gør ikke den imaginære transformation mindre forjættende for de unge modtagere - eller mindre dobbelttydig. Melodramaer har aldrig været entydige størrelser, hverken på lærredet eller i livet.

IIvor intet andet er novnt, er udenlandske citater oversat af forfatteren. 
1. Der hersker stor uenighed om definitionen af melodramaet: er det en æstetisk genre, eller betegner det en bredere (populær)kulturel form? Jeg vælger $\mathrm{i}$ det følgende den brede definition, idet den tillader en kulturanalytisk kobling til modernitet. En fin introduktion til melodrama findes iøvrigt in Gerould (1981), som også indeholder en omfattende bibliografi. Det romantiske melodrama behandles glimrende in Gledhill (1987).

2. Ligesom det er tilfældet i dag, foretrækker unge mænd i 1946 visuel fiktion og/eller faglige emner, mens unge kvinder mere vælger trykt fiktion. Således dokumenterer Ungdomskommissionen ikke alene, at mændene går mere $\mathrm{i}$ biografen, men også at de læser flere seriehæfter, hvor illustrationer jo er vigtige (Kurt Danner og Ole $\mathrm{Ny}$ er topscorerne). Ugebladslasning holder begge køn lige meget af. Af ugifte unge under 20 år er det således mellem $81 \%$ og $92 \%$, der læser ugeblade. I samme gruppe er hovedstadens unge de flittigste boglæsere, men i modsætning til resten af landet læser de københavnske kvinder mindre: $71 \%$ af dem har læst en bog inden for den sidste måned, mod mændenes $76 \%$. Omvendt er der flere mænd, der læser avis regelmæssigt, og kønsforskellen er mest fremtrædende for unge under 20 år: i provinsbyerne, som har de ivrigste avislæsere, læser $85 \%$ af mændene avis dagligt, mod $66 \%$ af kvinderne (Ungdomskommissionen 1951: 180, 182, 171, 183, 168).

Men trods disse vigtige kønsforskelle $\mathrm{i}$ mediebrug må det understreges, at medierne $\mathrm{i}$ almindelighed synes at have stor betydning for unges selvforståelse og kulturelle tolkning også i 1940'erne, hvor medieudbuddet jo var begrænset set med vore øjne (Ungdomskommissionens tal er indsamlet i 1946). Således har jeg fundet $i$ en igangværende unders $\varnothing$ gelse af unge kvinders kultur siden 1940 'erne, at ældre kvinder ofte binder erindringer om deres ungdomstid til mediebegivenheder (ture med Malmøbådene for at se Borte med Blasten for eksempel).

3. Termen skuelyst (Schaulust) er hentet hos Freud, som eksplicit kobler visuel og seksuel nydelse. Begrebet udfoldes således første gang i forbindelse med Freuds analyse af en kvindes drøm, hvis manifeste indhold er et teaterbes $\varnothing \mathrm{g}$ : »Naive unge piger siges efter deres forlovelse ofte at give udtryk for, at de nu snart må gå til alle hidtil forbudte stykker i teatret - at de må få lov til at se alt. Den nysgerrighed eller lyst til at »kigge« [Schaulust], der her kommer til udtryk, var sikkert oprindelig en seksuel nysgerrighed, der navnlig rettedes mod forældrenes kønsliv og blev derpå til et stærkt motiv, som tilskyndede pigerne til tidligt ægteskab« (Freud 1972: 179).

Teorien om skuelyst som et kønnet begreb udvikles blandt andet $\mathrm{i}$ psykosemiotisk filmteori ud fra en mandlig synsvinkel. Men det er altså karakteristisk, at kritikere meget tidligt søger at vaccinere sig selv mod det visuelles seksuelle komponenter ved at definere film som (udtryk for) det kvindelige. Herved distancerer kritikerne sig, samtidig med at de peger på deres eget begær.

4. Denne analysestrategi genfindes $i$ et af Kracauers hovedværker From Caligari 
to Hitler: A Psychological History of the Gernan Film (Princeton: Princeton University Press 1947). Bogen, som han skrev på engelsk efter sin emigration til USA i 1941, udkom på tysk i stærkt forkortet form i $1958 \mathrm{og}$ i en fuldstændig udgave i 1979.

5. Adorno antyder $\mathrm{i}$ en artikel om Kracauer (Adorno 1981: 397), at Kracauers latterliggørelse af de unge ekspeditricer og deres filmvalg netop skjuler hans egen fascination af de selvsamme film.

6. Uden at ville harmonere Freud og Lacan skal det nævnes, at man også inden for lacaniansk teori kan opfatte modsætningen mellem det Symbolske og det Imaginære som et spændingsforhold, der følger os hele livet, snarere end som stadier på livets vej. Netop dette spændingsforhold åbner for, at for eksempel Roland Barthes kan skelne mellem to former for lyst: det Imaginares jouissance, som ikke er rettet mod et bestemt driftsmål, og det Symbolskes plaisir, som er en objektrettet lyst, dvs begær. Netop denne skelnen kaster lys over de komplekse lystoplevelser, som jeg mener melodramaets narrative polariseringer lægger op til: det er muligt at veksle mellem de to positioner. Jeg foretrækker derfor at tale om kvindelig lyst, et begreb der både omfatter den ikke-objektrettede følelsesintensitet, og det objektrettede begar.

Når jeg i denne sammenhæng holder mig til mere klassisk freudiansk teori skyldes det, at hverken Lacan eller de feministiske teoretikere, han har inspireret, har nogen som helst indreflekterede begreber om alder eller udviklingsfaser $i$ deres psykoanalytiske teorier. Her åbner Freud for en mere dynamisk forståselse af for eksempel puberteten som en fase, der ikke blot gentager infantile konflikter, men som tillige tillader en revision af disse konflikter og hermed en nyudvikling af personligheden.

\section{Litteratur}

Adorno, Theodor. 1981. »Der wunderliche Realist«. In Noten zur Literatur. III. Frankfurt am Main: Suhrkamp. Opr. 1965.

Altenloh, Emilie. 1914. Zur Soziologie des Kino: Die Kino-Unternehmung und die sozialen Schichten ihrer Besucher. Leipzig: Spamerschen Buchdruckerei.

Alkjar, Ejler. 1956. Ungdommen på det danske marked: en analyse af de 14-19 åriges indvirkning på købe- og forbrugsvanerne. København: Aller.

Allen, Robert. 1980. Vaudeville and Film, 1895-1915: a Study in Media Interaction. New York: Arno Press.

Ang, Ien. 1985. Watching Dallas: Soap Opera and the Melodramatic Imagination. London: Methuen.

Berthelsen, Carsten. 1989. »En verden af billeder: om levende billeder og billedoplevelse«. In Carsten Frederiksen. Red. Den hellige skrift: en bog om bøger og billedmedier. Valby: Danmarks Biblioteksforenings Forlag: 125-46.

Blos, Peter. 1969. Om ungdomsårene: en psykoanalytisk belysning. København: Hans Reitzel. Overs. Nina Lautrup-Larsen. Opr. 1962. 
Bolvig, Kirsten et al. 1971. Søndags-B.T.: rapport om en succes. København: Gyldendal.

Briggs, Sir Asa. 1960. Mass Entertainment: the Origins of A Modern Industry. Adelaide: Griffin.

Brooks, Peter. 1976. The Melodramatic Imagination: Balzac, Henry James, Melodrama, and the Mode of Excess. New York: Columbia University Press.

Chasseguet-Smirgel, Janine. 1980. »Den kvindelige skyldfølelse«. In Tania Ørum. Red. Kvindelighed: $k v i n d e f r i g \phi r e l s e ~ o g ~ p s y k o a n a l y s e$. En antologi. København: Tiderne Skifter: 53-112. Overs. Karen Nikolajsen. Opr. 1964.

de Lauretis, Teresa. 1987. Technologies of Gender: Essays on Theory, Film and Fiction. Bloomington, Indianpolis: Indiana University Press.

Dinnesen, Niels Jørgen og Edvin Kau. 1983. Filmen i Danmark. København: Akademisk Forlag.

Drotner, Kirsten. 1988. English Children and Their Magazines, 1751-1945. New Haven: Yale University Press.

Drotner, Kirsten. 1990a. "Intensities of Feeling: Modernity, Melodrama, Adolescence $\ll$, Theory, Culture and Society 7, nr 4: 57-89.

Drotner, Kirsten. 1990b. "Modernitet og mediepanikk«. In Trine DeichmanSørensen og Ivar Frønes. Red. Kulturanalyse. Oslo: Gyldenđal Norsk Forlag: 131-59.

Drotner, Kirsten. 1991. At skabe sig - selv: ungdom, astetik, padagogik. København: Gyldendal.

Ewen, Stuart og Elizabeth. 1982. Channels of Desire: Mass Images and the Shaping of American Consciousness. New York: McGraw-Hill.

Freud, Sigmund. 1972. Forelasninger til indføring i psykoanalysen. København: Hans Reitzel. Overs. Mogens Boisen. Opr. 1916.

Fridberg, Torben. 1989. Danskerne og kulturen. København: Socialforskningsinstituttet.

Gerould, Daniel. 1981. Red. Melodrama. VII. New York: New York Literaty Forum.

Gledhill, Christine. 1987. Red. Home Is Where the Heart Is: Studies in Melodrama and the Woman's Film. London: British Film Institute.

Hansen, Miriam. 1983. »Early Silent Cinema: Whose Public Sphere? New German Critique 29: 147-84.

Hobson, Dorothy. 1982. Crossroads: the Drama of a Soap Opera. London: Methuen.

Huyssen, Andreas. 1986. "Mass Culture As Woman: Modernism's Other", in Tania Modleski. Red. Studies in Entertainment: Critical Approaches to Mass Cullure. Blóomington, Indianapolis: Indiana University Press: 188-207.

Jacobs, Lewis. 1968. The Rise of American Film: a Critical History. New York: Teachers College Press. Opr. 1939.

Jowett, Garth. 1976. Film: the Democratic Art. Boston: Little, Brown \& Co.

Kracauer, Siegfried. 1927. "Das Ornament der Masse«. Overs. in Bent Fausing og Peter Larsen. 1980. Red. Visuel kommunikation. II. København: Medusa. Overs. 
Mette Rønn.

Kracauer, Siegfried. 1977. »Die kleinen Ladenmädchen gehen ins Kino«. In: hans Das Ornament der Masse: Essays. Frankfurt am Main: Suhrkamp: 279-94. Opr. 1927.

Kuhn, Annette. 1984. »Women's Genres: Melodrama, Soap Opera and Theory«, Screen 25, nr 1: 18-28.

Laplace, Maria. 1987. »Producing and Consuming the Woman's Film: Discursive Struggle in Now Voyager «, in Gledhill 1987: 138-66.

Merrit, Russell. 1976. $\gg$ Nickelodeon Theaters, 1905-14: Building an Audience for the Movies«. In Tino Balio. Red. The American Film Industry. Madison: University of Wisconsin Press: 59-70.

Modleski, Tania. 1982. Loving With a Vengeance: Mass-Produced Fantasies for Women. Hamden, Ct. Archon.

Modleski, Tania. 1986. »Femininity as Mas[s]querade: A Feminist Approach to Mass Culture, in Colin McCabe. Red. High Theory/Low Culture: Analysing. Popular Television and Film. Manchester: Manchester University Press.

Mulvey, Laura. 1975. „Visual Pleasure and Narrative Cinema«, Screen 16, ní 3: 618.

Mulvey, Laura. 1989. Visual and Other Pleasures. Bloomington, Indianapolis: Indiana University Press.

Møller, Hanne et al. 1972. Udsigten fra det kvindelige univers: en analyse af Eva. København: Røde Hane.

Povlsen, Karen Klitgaard. 1986. Blikfang: om kvindecestetik og dameblade. Aalborg: Aalborg Universitetsforlag.

Radway, Janice. 1984. Reading the Romance: Women, Patriarchy and Popular Literature. Chapel Hill: University of North Carolina Press.

Richards, Jeffrey. 1984. The Age of the Dream Palace: Cinema and Society in Britain, 1930-1939. London: Routledge.

Silverman, Kaja. 1988. The Acoustic Mirror: the Female Voice in Psychoanalysis and Cinema. Bloomington, Indianapolis: Indiana University Press.

Ungdomskommissionen. 1951. Den danske ungdom: en statistisk undersøgelse foretaget af ungdomskommissionen. København: J. H. Schultz.

Viviani, Christian. 1987. »Who Is Without Sin? The Maternal Melodrama in American Film, 1930-39«, in Christine Gledhill. Red. Home Is Where the Heart Is: Studies in Melodrama and the Woman's Film. London: Btitish Film Institute: 83-99. Overs. D. Burdick. 